\title{
Filobasidiella lutea: parasitism of Hypochnicium vellereum
}

\author{
J. GINNS and ANNAROSA BERNICCHIA
}

GINNS, J. \& BERNICCHIA, A. 2000: Filobasidiella lutea: parasitism of Hypochnicium vellereum. - Karstenia 40: 49-51. Helsinki. ISSN 0453-3402.

The presence of haustorial branches and a restricted host range suggest that Filobasidiella lutea is a mycoparasite. Microscopic features are illustrated from recent Italian collections.

Key words: Filobasidiella, fungi, mycoparasite, systematics

J. Ginns, Eastern Cereals and Oilseed Research Centre, AAFC, Ottawa, ON, KIA OC6 Canada. E-mail: ginnsj@em.agr.ca. Current address: Pacific Agriculture Research Centre, 4200 Highway 97, Summerland, British Columbia, V0H 1Z0, Canada

Annarosa Bernicchia, Istituto di Patologia Vegetale, Università Delgi Studi, 40126 Bologna, Italia. E-mail: abernicc@pop.agrsci.unibo.it

\section{Introduction}

Collecting of wood decaying Basidiomycetes in Italy yielded two specimens of an unusual, recently described fungus named Filobasidiella lutea P. Roberts (1997). The fungus, until now known from only six localities in England, grew on basidiomes of Hypochnicium vellereum (Ellis \& Cragin) Parmasto (Hyphodermataceae). The purpose of this paper is to confirm the connection between $F$. lutea and its host, document variability in some morphological features, and extend the geographic range.

\section{Methods}

The standard mounting media for microscopic examination of specimens of Hymenomycetes were used, i.e., Melzer's reagent, 2\% potassium hydroxide, aqueous phloxine, and cotton blue in lactic acid. The formulae for these can be found in Boidin (1958), Hawksworth et al. (1995), Hjortstam et al. (1987) and Smith et al. (1981). Abbreviations for herbaria where specimens are preserved follow Holmgren et al. (1990).
Filobasidiella lutea P. Roberts, Mycotaxon 63: 198, 1997.-Fig. 1

Basidiomes effuse, inconspicuous, typically several $\mathrm{cm}$ long and broad, some nearly $0.3 \mathrm{~mm}$ thick, adnate. Hymenial surface smooth, arid, powdery, buff color. Margin indistinct. Subiculum a loose web of hyphae within the basidiome of the host.

Hyphal system monomitic. Generative hyphae simple septate, with rare clamp connections, 2-3 $\mu \mathrm{m}$ diam, the walls thin, hyaline, blue in cotton blue, nonamyloid, nondextrinoid. Haustorial branches broadly clavate, about $4 \mu \mathrm{m}$ long, simple septate at the base, most with one or two truncated appendages up to $2 \mu \mathrm{m}$ long that are appressed to hyphae of the host $H$. vellereum. Basidia subtended by an inverted T-shaped foot-cell that links each basidium to the my- 


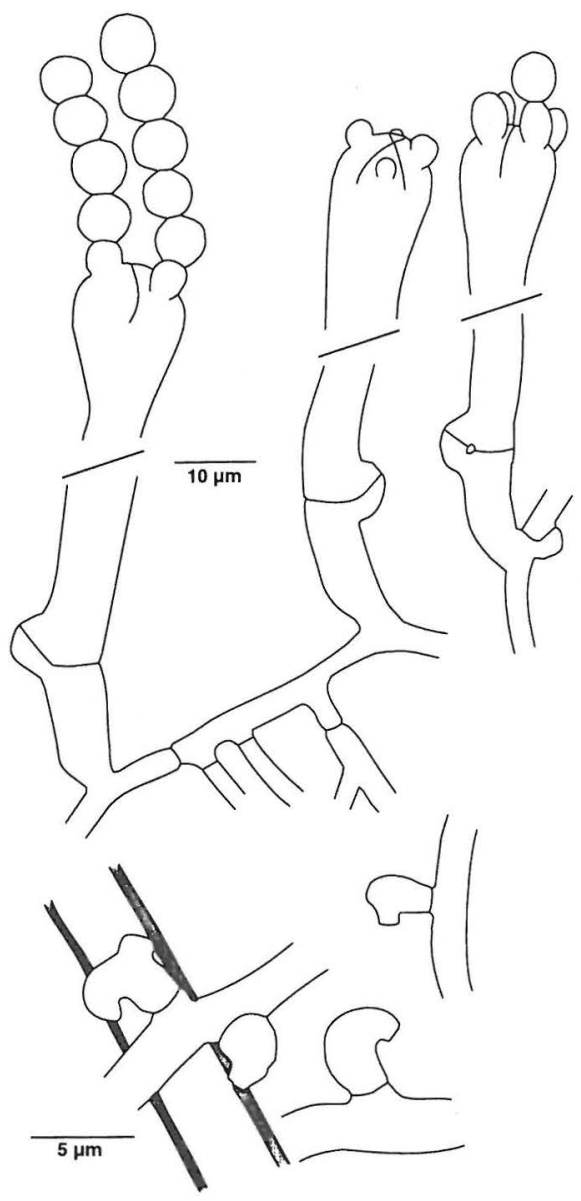

Fig. 1. Filobasidiella lutea. Three basidia attached to subicular hyphae (above), and four haustorial branches, the two on left attached to a hypha of the host, $\mathrm{Hy}$ pochnicium vellereum, shown with shaded walls. All from Bernicchia 6702.

celium. Foot-cells about $6 \mu \mathrm{m}$ diam at the basidial base, tapering to $3 \mu \mathrm{m}$ diam where the stem of the T-cell joins the main portion of the hypha, the stem typically $10-20 \mu \mathrm{m}$ long, but some up to 40 $\mu \mathrm{m}$. Basidia clavate, $(200-)$ 240-290 (-310) $\times 12-$ $13 \mu \mathrm{m}(\mathrm{n}=11)$, each with a single clamp connection at the base, the basidial stem about 210-240 $\mu \mathrm{m}$ long and 5-9 $\mu \mathrm{m}$ diam, cylindrical, the inflated basidial apex about $30 \mu \mathrm{m}$ long, the walls thin to $0.5 \mu \mathrm{m}$ thick, hyaline, blue in cotton blue, nonamyloid, nondextrinoid, cruciately septate with the septa extending $6 \mu \mathrm{m}$ into the apex of the basidium. Sterigmata lacking. Basidiospores developing as obovoid buds from the basidial apex, one bud arising in each of the four compartments delimited by the apical septa. Basidiospores when mature globose to subglobose with the basal side slightly truncated, (5.5-) 6.0-6.5 (-7.0) $\mu \mathrm{m}(\mathrm{n}=21)$, catenulate, the walls smooth, about $0.5 \mu \mathrm{m}$ thick, hyaline, dextrinoid, dark blue in cotton blue. Spore germination not seen.

Habitat. Over the hymenial surface of $\mathrm{Hy}$ pochnicium vellereum basidiomes that grew on rotted wood of Ulmus glabra Huds. and unspecified species of Ulmus.

Specimens examined: Italy: Parco Naz. Foreste Casentinesi, Riserva di Badia Prataglia: Lama: loc. Fornino (Forli), 700 m, I.G.M.: 25,000, 265-II, on rotted wood Ulmus glabra, 17.X.1996 A. Bernicchia 6702 (DAOM, HUBO); 13.X.1996 A. Bernicchia 6703 (HUBO).

\section{Discussion}

Some parasitic fungi have a very narrow host range and Filobasidiella lutea may be one such species. Although described only three years ago, the ten known collections of $F$. lutea are all on the hymenial surfaces of Hypochnicium vellereum. How frequently $F$. lutea colonizes $H$. vellereum is uncertain. Examination of 42 collections of $H$. vellereum by JG (at BPI) failed to reveal any $F$. lutea. Even though eight were on $U l$ mus. However, 39 were from the United States and Canada, with only one each from England, Italy and Japan.

The efficiency of the mode of dispersal of mycoparasitic fungi is intriguing. Random dispersal of air-borne spores would seem to have a low chance of landing on a host that is small and widely scattered. Filobasidiella lutea's copious, loosely attached, statimospores and both the host fungus's relatively small size (basidiomes of $H$. vellereum are typically a few $\mathrm{cms}$ long and broad), and its habit (partially hidden basidiomes on the lower surfaces of dead branches and stems) suggest dispersal by an insect or arachnid vector. The vector may locate $H$. vellereum by following an aroma produced by $H$. vellereum.

The Italian specimens enable us to expand upon several morphological features of $F$. lutea. First, although a clamp connection is present at the base of each basidium, they were rare on the hyphae. The basal clamp connection strongly suggests that meiosis occurs in the basidium. Second, the description of the foot-cell at the base of each basidium confirms the connection 
between the basidium and the mycelium, and its presence indicates that there is no development of a distinct subhymenial tissue. Third, hyphae of $F$. lutea were $300 \mu \mathrm{m}$ below the hymenial surface in $H$. vellereum basidiomes. Whether hyphae extended below the Hypochnicium basidiome is not known but it seems unlikely considering the parasitic nature of $F$. lutea. Fourth, the haustorial branches, best seen in phloxine mounts because they stained deep red, were subtended by a simple septum and they were common in some areas of the host basidiome, i.e., five haustorial branches were seen along a $30 \mu \mathrm{m}$ section of a $H$. vellereum hypha. Fifth, cyanophily was observed in walls of spores, basidia and hyphae. Roberts (1997) reported spore walls to be cynaophilous. Finally, the connection between the catenate spores was fragile because chains of spores were rarely seen, whereas individual spores floating in mounts were common. Roberts (1997) illustrated a disjunctor between the spores in a chain, but this was not seen by us.

Three species comprise the genus Filobasidiella. The principal morphological feature of the genus Filobasidiella is the production by budding of catenulate basidiospores from four sites on the apex of the basidium. Morphologically $F$. neoformans Kwon-Chung (1998) has a clamp connection at each septum, haustorial branches and a yeast stage. Whereas, $F$. depauperata (Petch) Samson et al. (1983) lacks these three features. Filobasidiella lutea has a clamp connection at the base of each basidium but clamp connections on the hyphae are rare. Like $F$. neoformans, $F$. lutea has haustorial branches but these branches in the two species differ in morphology. And, perhaps because it has not been cultured, a yeast stage has not been seen in $F$. lutea. All three species are parasitic. Filobasidiella neoformans is a parasite of mammals, $F$. depauperata appears to be a parasite of Verticillium species that are entomopathogenic, and $F$. lutea is also mycoparasitic (Kwon-Chung 1998, Roberts 1997, Samson et al. 1983).

The occurrence of basidia with a partially septate apex is unusual. However, in Filobasidiella they are known in F. lutea, where all basidia we observed were partially septate, and in F. depauperata some basidia are partially septate(KwonChung 1998). Such septa also occur in some species of the genera Metabourdotia L.S. Olive (1957), Pseudotulasnella Lowy (1964), Rhyn- chogastrema B. Metzler \& Oberw. (1989), Syzygospora G.W. Martin (Ginns 1986) and Tremellodendropsis (Corner) D.A. Crawford (Corner 1966). The presence of partial septa does not appear to indicate a close relationship because two of the five genera are in the Tremellales, one each is in the Ceratobasidiales and Tulasnellales (Hawksworth et al. 1995), while Filobasidiella is placed in the Filobasidiales (Roberts 1997).

Acknowledgments: Dr. R.J. Bandoni, Vancouver, provided constructive comments on the systematics of this group. Dr. Peter Roberts, Kew, critically reviewed the manuscript. Drs. Amy Rossman and David Farr were most cooperative during my February 1998 visit to The National Fungus Collections, Beltsville.

\section{References}

Boidin, J. 1958: Essai biotaxonomique sur les Hydnés Résupinés et les Corticiés. - Rev. Mycol. (Paris). Mém. hors-sér. 6: 1-387.

Corner, E.J.H. 1966: The clavarioid complex of Aphelaria and Tremellodendropsis. - Trans. Br. Mycol. Soc. 49: 205-211.

Ginns, J. 1986: The genus Syzygospora (Heterobasidiomycetes: Syzygosporaceae). - Mycologia 78: 619636.

Hawksworth, D.L., Kirk, P.M., Sutton, B.C. \& Pegler, D.N. 1995: Ainsworth \& Bisby's dictionary of the fungi. 8th $\mathrm{Ed}$. - $\mathrm{CAB}$ International, Wallingford, United Kingdom. 616 pp.

Hjortstam, K., Larsson, K.-H., \& Ryvarden, L. 1987: Introduction and keys. - Corticiaceae of North Europe 1: 1-59.

Holmgren, P.K., Holmgren, N.H. \& Barnett,L.C. 1990: Index Herbariorum, Part I. 8th Ed. - Regnum Vegetabile 120: 1-693.

Kwon-Chung, K.J. 1998: 82. Filobasidiella KwonChung. pp. 656-663. - In: Kurtzman, C.P. \& Fell, J.W. (eds.). The Yeasts, A taxonomic study. $4^{\text {th }}$ ed. Elsevier, Amsterdam.

Lowy, B. 1964: A new genus of the Tulasnellaceae. Mycologia 56: 696-700.

Metzler, B., Oberwinkler, F. \& Petzold, H. 1989: Rhynchogastrema gen. nov. and Rhynchogastremaceae fam. nov. (Tremellales). - Syst. Appl. Microbiol. 12: 280-287.

Olive, L.S. 1957: Two new genera of the Ceratobasidiaceae and their phylogenetic significance. - Amer. J. Bot. 44: 424-435.

Roberts, P. 1997: New Heterobasidiomycetes from Great Britain. Mycotaxon 63: 195-216.

Samson, R.A., Stalpers, J.A. \& Weijman A.C.M. 1983: On the taxonomy of the entomogenous fungus Filobasidiella arachnophila. - Antonie van Leeuwenhoek 49: $447-456$.

Smith, A.H., Smith, H.V. \& Weber, N.S. 1981: How to know the non-gilled mushrooms. 2nd ed. - W.C. Brown Co., Dubuque, Iowa. 324 pp. 